\title{
Late discovery of left atrial appendage occluder device embolization: a case report
}

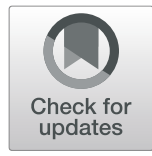

\author{
Mohamad Jihad Mansour ${ }^{1,2,3}$, Clément Bénic ${ }^{2,3}$, Romain Didier ${ }^{2,3}$, Antoine Noel ${ }^{2,3}$, Martine Gilard ${ }^{2,3}$ and \\ Jacques Mansourati ${ }^{2,3^{*}}$ (D)
}

\begin{abstract}
Background: Left atrial appendage (LAA) closure has been well evaluated in the prevention of stroke in patients with atrial fibrillation. Device embolization remains one of the most common complications. To the best of our knowledge, there have been no reports of late discovery of LAA occluder device embolization at 1.5 years after implantation.
\end{abstract}

Case presentation: We describe the case of a 77-year-old man who underwent uneventful LAA closure. Echocardiography performed the next day showed the device in place. The patient was discharged but was then lost to follow-up. 1.5 years later, he was admitted for ischemic stroke. Transesophageal echocardiography showed the absence of the occluder device in the LAA. Computed tomography scan of the abdomen showed the device in the abdominal aorta. Due to the high cardiovascular risk, the device was kept in place and the patient was treated medically.

Conclusions: Per-procedural and late device embolization are not uncommon. Review of the literature however showed no report of late discovery of device embolization at 1.5 years. Follow-up echocardiography is mandatory for the detection of endothelialization or embolization.

Keywords: Left atrial appendage closure, Watchman device, Atrial fibrillation, Stroke, Echocardiography, Case report

\section{Background}

Several studies have evaluated different left atrial appendage (LAA) occluder devices and demonstrated noninferiority in stroke prevention compared to warfarin in patients with atrial fibrillation (AF) [1, 2]. Early device embolization remains one of the most common complications, which requires urgent extraction. We herein describe a case of late discovery of an occluder device embolization that was not extracted but rather medically managed.

\footnotetext{
* Correspondence: jacques.mansourati@chu-brest.fr

${ }^{2}$ Department of Cardiology, University Hospital of Brest, Brest, Cedex 29609, France

${ }^{3}$ Université de Bretagne Occidentale, Brest, France

Full list of author information is available at the end of the article
}

\section{Case presentation}

A 77-year-old male patient with a medical history significant for permanent AF with a $\mathrm{CHA}_{2} \mathrm{DS}_{2}$-VASC score of 6 , ischemic stroke with residual seizure and two hemorrhagic strokes, was referred for LAA closure using a Watchman device (Boston Scientific, Inc., Natick, Massachusetts). LAA morphology and measurements were obtained from cardiac computed tomography (CT) angiography and transesophageal echocardiography (TEE). LAA was bilobed. The maximum width of the ostium was measured at $20 \mathrm{~mm}$. Hence, a $24 \mathrm{~mm}$ device was successfully implanted. The device was well aligned with the axis of the LAA. A gentle tug test did not change the device position. The patient remained stable and there were no complications noted during or after the procedure. Transthoracic echocardiography (TTE) performed

(c) The Author(s). 2020 Open Access This article is licensed under a Creative Commons Attribution 4.0 International License, which permits use, sharing, adaptation, distribution and reproduction in any medium or format, as long as you give appropriate credit to the original author(s) and the source, provide a link to the Creative Commons licence, and indicate if changes were made. The images or other third party material in this article are included in the article's Creative Commons licence, unless indicated otherwise in a credit line to the material. If material is not included in the article's Creative Commons licence and your intended use is not permitted by statutory regulation or exceeds the permitted use, you will need to obtain permission directly from the copyright holder. To view a copy of this licence, visit http://creativecommons.org/licenses/by/4.0/ The Creative Commons Public Domain Dedication waiver (http://creativecommons.org/publicdomain/zero/1.0/) applies to the data made available in this article, unless otherwise stated in a credit line to the data. 
the next day showed the device in place. The patient was discharged with a scheduled TEE six weeks after the procedure but was lost to follow-up.

1.5 years later, he presented with two new ischemic strokes and unexplained left foot pain. Repeat TTE/TEE showed the absence of the occluder device in the LAA. CT scan of the chest and abdomen showed the device in the abdominal aorta between the ostium of the celiac trunk and the superior mesenteric artery (Fig. 1, Panels A-C). Mild thrombosis was seen in the device at the level of the fabric membrane (Panels B and D). The abdominal aorta was severely calcified (Panels A and C). Due to the high cardiovascular risk, surgical or percutaneous extraction were not done and the device was kept in place. Low dose aspirin was added to his medical treatment. The patient died 3 months later from seizure.

\section{Discussion and conclusions}

Complications of Watchman device implantation are rare, with device embolization rates of 0.6 and $0.7 \%$ [1, 2]. Device extraction can be performed either percutaneously via a snare introduced in the femoral artery sheath (e.g., for Watchman device), or surgically (for larger devices) [3]. Percutaneous removal remains the treatment of choice for vascular embolization, particularly in patients with multiple comorbidities and the elderly population. Device embolization risk depends on the operator's experience, the choice of device size and the final position. Patient related characteristics such as LAA morphology and length, ostium size or unusual morphologies are also important criteria. Per procedural TEE guidance is mandatory, thereby avoiding vigorous tug testing (usually performed for proof of device stability). Nevertheless, aggressive physical movements are not advised before endothelialization [4].

Published articles retrieved from PubMed database included single center/multicenter registries, randomized controlled trials, observational studies, case reports and a systematic review [3-24] (Table 1). Device embolization occurred mostly during the procedure and within 7 days in the described cases. Some cases reported embolization at 45 and 48 days $[3,16,19]$. A study published by Swaans et al. [5] described device embolization 3 months following the procedure. Another case described percutaneous retrieval of an AMPLATZER cardiac plug 6 months after embolization [23]. In a systematic review, Aminian et al. [24] concluded that embolization occurred mostly in the periprocedural period but late embolization was not uncommon. Review of the literature however showed no report of late discovery of device embolization at 1.5 years. Since in the majority of cases device embolization is asymptomatic, patient education for short and long term
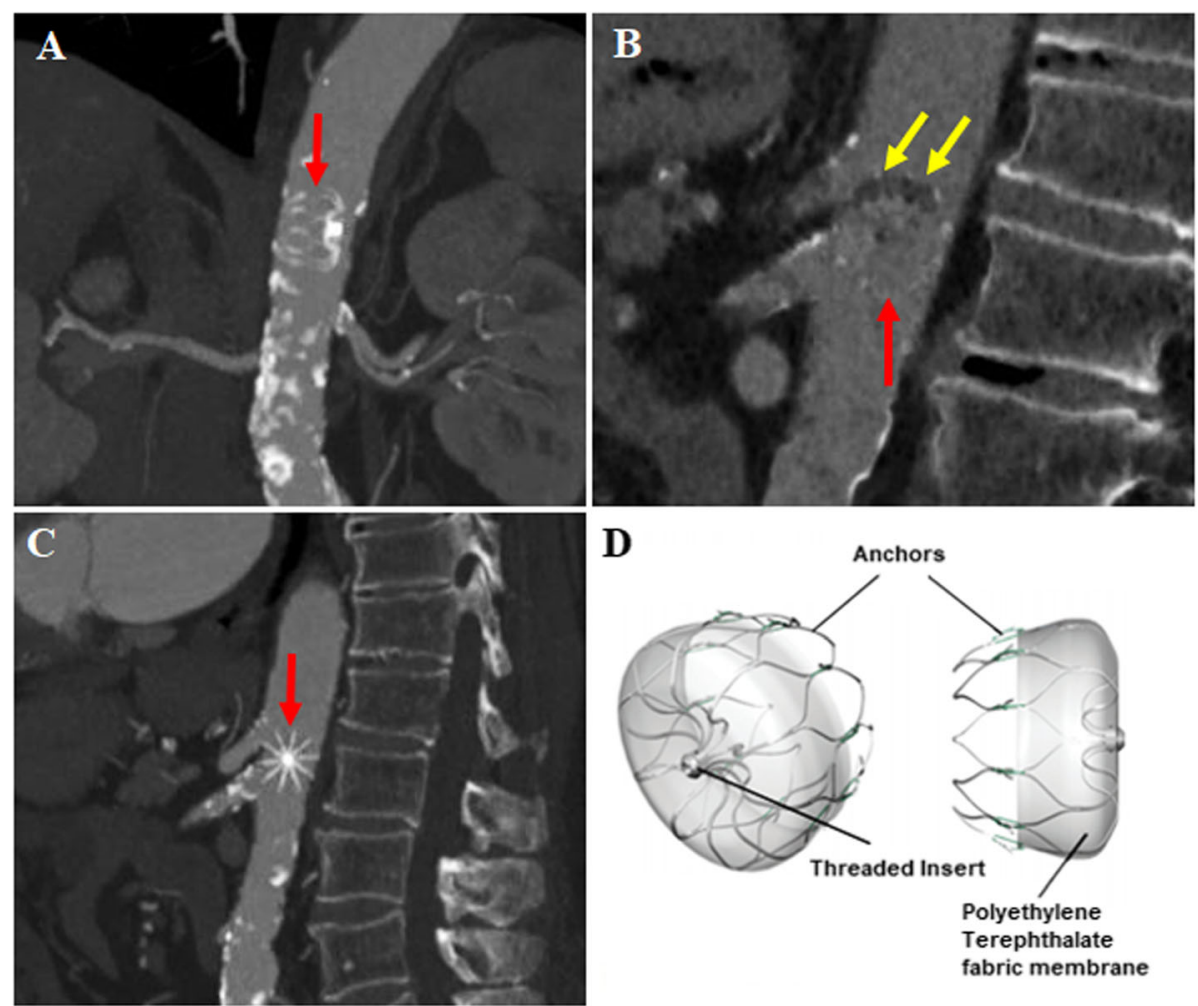

Fig. 1 Watchman device (red arrows) located in the abdominal aorta in coronal (a), sagittal right (b) and sagittal left (c) views. Note the mild thrombus formation in the device in panel B (yellow arrows). Panel $\mathbf{d}$ illustrates the general structure of the Watchman device 
Table 1 Summary of published data on Watchman device embolization

\begin{tabular}{|c|c|c|c|c|c|c|}
\hline Reference & Study Design & $\begin{array}{l}\text { Number of device } \\
\text { embolization }\end{array}$ & $\begin{array}{l}\text { Device } \\
\text { size }\end{array}$ & $\begin{array}{l}\text { Device } \\
\text { location }\end{array}$ & Timing & Retrieval Approach \\
\hline $\begin{array}{l}\text { Holmes et al. } \\
\text { [2] }\end{array}$ & $\begin{array}{l}\text { Randomized controlled trial } \\
(N=269)\end{array}$ & 2 & $27 \mathrm{~mm}$ & LV & $\begin{array}{l}\text { Post procedure day } \\
1\end{array}$ & Surgery \\
\hline $\begin{array}{l}\text { Holmes et al. } \\
\text { [3] }\end{array}$ & $\begin{array}{l}\text { Randomized non-inferiority } \\
\text { trial }(N=463)\end{array}$ & 3 & $30 \mathrm{~mm}$ & $\begin{array}{l}\text { LV } \\
\text { Thoracic } \\
\text { Aorta } \\
\text { AA }\end{array}$ & $\begin{array}{l}\text { Intraprocedural } \\
45 \text { days } \\
45 \text { days }\end{array}$ & $\begin{array}{l}\text { Surgery } \\
\text { Percutaneous (femoral - } \\
\text { snare) } \\
\text { Surgery }\end{array}$ \\
\hline Sick et al. [4] & Multicenter registry $(N=66)$ & 2 & NA & NA & Intraprocedural & $\begin{array}{l}\text { Percutaneous (femoral - } \\
\text { snare) }\end{array}$ \\
\hline $\begin{array}{l}\text { Swaans et al. } \\
\text { [5] }\end{array}$ & Single center registry $(N=30)$ & 1 & NA & AA & 3 months & Surgery \\
\hline Reddy et al. [6] & Multicenter registry $(N=150)$ & 2 & NA & $\begin{array}{l}\text { Descending } \\
\text { Aorta }\end{array}$ & Intraprocedural & $\begin{array}{l}\text { Percutaneous (femoral - } \\
\text { snare) }\end{array}$ \\
\hline $\begin{array}{l}\text { Matsuo et al. } \\
\text { [7] }\end{array}$ & Single center registry $(N=179)$ & 2 & NA & AA & $\begin{array}{l}\text { Post procedure } \\
\text { within } 12 \mathrm{~h}\end{array}$ & $\begin{array}{l}\text { Percutaneous (femoral - } \\
\text { snare) }\end{array}$ \\
\hline $\begin{array}{l}\text { Pérez Matos } \\
\text { et al. [8] }\end{array}$ & Case report & 1 & $27 \mathrm{~mm}$ & LV & $\begin{array}{l}\text { Post procedure day } \\
1\end{array}$ & $\begin{array}{l}\text { Transapical access and } \\
\text { pulling catheter }\end{array}$ \\
\hline $\begin{array}{l}\text { Chopra et al. } \\
\text { [9] }\end{array}$ & Case report & 1 & $34 \mathrm{~mm}$ & LA & $\begin{array}{l}\text { Post procedure day } \\
1\end{array}$ & Transseptal \\
\hline Vivek et al. [10] & $\begin{array}{l}\text { Registry } \\
(N=3822)\end{array}$ & 9 & NA & NA & NA & $\begin{array}{l}6 \text { surgery } \\
3 \text { Percutaneous }\end{array}$ \\
\hline $\begin{array}{l}\text { Boersma et al. } \\
\text { [11] }\end{array}$ & Cohort $(N=1025)$ & 2 & NA & NA & Within 7 days & $\begin{array}{l}1 \text { surgery } \\
1 \text { percutaneous }\end{array}$ \\
\hline Vivek et al. [12] & $\mathrm{RCT}(N=707)$ & 3 & NA & NA & Early & NA \\
\hline $\begin{array}{l}\text { Pillarisseti et al. } \\
\text { [13] }\end{array}$ & $\begin{array}{l}\text { Multicenter observational } \\
\text { study }(N=478)\end{array}$ & 1 & NA & NA & NA & Surgery \\
\hline Betts et al. [14] & $\begin{array}{l}\text { Multicenter retrospective } \\
\text { registry }(N=371)\end{array}$ & 1 & NA & NA & Per procedure & NA \\
\hline Saw et al. [15] & Multicenter experience & 1 & NA & NA & Early & Percutaneous -Snared \\
\hline $\begin{array}{l}\text { Fanari et al. } \\
\text { [16] }\end{array}$ & Case report & 1 & $21 \mathrm{~mm}$ & AA & 48 days & Percutaneous \\
\hline $\begin{array}{l}\text { Gabriels et al. } \\
\text { [17] }\end{array}$ & Case report & 1 & $24 \mathrm{~mm}$ & LA & Intraprocedural & Percutaneous - transseptal \\
\hline $\begin{array}{l}\text { Fastner et al. } \\
\text { [18] }\end{array}$ & Case report & 1 & NA & LA & Intraprocedural & Percutaneous \\
\hline $\begin{array}{l}\text { Hai Deng et al. } \\
\text { [19] }\end{array}$ & Case report & 1 & $30 \mathrm{~mm}$ & Aortic arch & 45 days & Percutaneous - snared \\
\hline $\begin{array}{l}\text { Stollberger } \\
\text { et al. [20] }\end{array}$ & Case report & 1 & $30 \mathrm{~mm}$ & LV & Periprocedural & Surgery \\
\hline Barth et al. [21] & Case Report & 2 & $\begin{array}{l}24 \mathrm{~mm} \\
21 \mathrm{~mm}\end{array}$ & $\begin{array}{l}\text { LA } \\
\text { Descending } \\
\text { Aorta }\end{array}$ & Periprocedural & $\begin{array}{l}\text { Percutaneous - transseptal } \\
\text { Percutaneous -Snared }\end{array}$ \\
\hline $\begin{array}{l}\text { Bôsche et al. } \\
\text { [22] }\end{array}$ & $\begin{array}{l}\text { Single center prospective } \\
\text { study }\end{array}$ & 1 & NA & NA & Within 7 days & Percutaneous \\
\hline $\begin{array}{l}\text { Obeid et al. } \\
\text { [23] }\end{array}$ & Case report & 1 & $24 \mathrm{~mm}$ & LA & 6 months & Percutaneous \\
\hline $\begin{array}{l}\text { Aminian et al. } \\
{[24]}\end{array}$ & Systematic Review & 21 & NA & $\begin{array}{l}9 \text { Aorta } \\
9 \text { LV } \\
3 \text { LA }\end{array}$ & Until 90 days & $\begin{array}{l}\text { Surgical } \\
\text { Percutaneous }\end{array}$ \\
\hline
\end{tabular}

$A A$ abdominal aorta, $L A$ left atrium, $L V$ left ventricle, $N A$ not applicable

follow-up is extremely important as there is no way to know the exact timing of device embolization. Hence, in our case, embolization could have occurred earlier but was lately picked up due to loss of follow-up.
We report a unique case of late discovery of LAA occluder device embolization in the abdominal aorta. Per procedural and follow-up echocardiography is crucial for the detection of device endothelialization or embolization. 


\section{Abbreviations}

AF: Atrial fibrillation; CT: Computed tomography; LAA: Left atrial appendage; TEE: Transesophageal echocardiography; TTE: Transthoracic echocardiography

\section{Acknowledgments}

This article was also published as an abstract in EP Europace [25]

\section{Authors' contributions}

MJM collected the data and drafted the manuscript, CB reviewed the literature and contributed in data interpretation, $\mathrm{RD}$ and $\mathrm{MG}$ revised the manuscript, AN took care of the patient and contributed in the conception and design of the manuscript, and JM extensively revised the manuscript and was the main investigator. All authors read and approved the final manuscript.

\section{Funding}

Not applicable.

\section{Availability of data and materials}

Not applicable.

\section{Ethics approval and consent to participate}

Not applicable.

\section{Consent for publication}

Patient's next-of-kin gave written consent for their relatives personal or clinical details along with any identifying images to be published in this manuscript.

\section{Competing interests}

Professor Jacques Mansourati is consultant and receives research fees from Boston Scientific and Abbott Laboratories. All other authors declare that they have no competing interests.

\section{Author details}

'Division of Cardiology, Lebanese University, Faculty of Medical Sciences, Beirut, Lebanon. ${ }^{2}$ Department of Cardiology, University Hospital of Brest, Brest, Cedex 29609, France. ${ }^{3}$ Université de Bretagne Occidentale, Brest, France.

Received: 27 February 2020 Accepted: 16 June 2020

Published online: 22 June 2020

\section{References}

1. Fountain RB, Holmes DR, Chandrasekaran K, Packer D, Asirvatham S, Van Tassel R, et al. The PROTECT AF (WATCHMAN left atrial appendage system for embolic PROTECTion in patients with atrial fibrillation) trial. Am Heart J. 2006 May; 151(5):956-61.

2. Holmes DR, Kar S, Price MJ, Whisenant B, Sievert H, Doshi SK, et al. Prospective randomized evaluation of the watchman left atrial appendage closure device in patients with atrial fibrillation versus long-term warfarin therapy: the PREVAIL trial. J Am Coll Cardiol. 2014;64(1):1-12.

3. Holmes DR, Reddy VY, Turi ZG, Doshi SK, Sievert H, Buchbinder M, et al. Percutaneous closure of the left atrial appendage versus warfarin therapy for prevention of stroke in patients with atrial fibrillation: a randomised noninferiority trial. Lancet Lond Engl. 2009:374(9689):534-42.

4. Sick PB, Schuler G, Hauptmann KE, Grube E, Yakubov S, Turi ZG, et al. Initial worldwide experience with the WATCHMAN left atrial appendage system for stroke prevention in atrial fibrillation. J Am Coll Cardiol. 2007 Apr 3; 49(13):1490-5.

5. Swaans MJ, Post MC, Rensing BJWM, Boersma LVA. Ablation for atrial fibrillation in combination with left atrial appendage closure: first results of a feasibility study. J Am Heart Assoc. 2012 Oct;1(5):e002212.

6. Reddy WY, Möbius-Winkler S, Miller MA, Neuzil P, Schuler G, Wiebe J, et al. Left atrial appendage closure with the watchman device in patients with a contraindication for oral anticoagulation: the ASAP study (ASA Plavix feasibility study with watchman left atrial appendage closure technology). J Am Coll Cardiol. 2013 Jun 25;61(25):2551-6.
7. Matsuo Y, Sandri M, Mangner N, Majunke N, Dähnert I, Schuler G, et al. Interventional closure of the left atrial appendage for stroke prevention. Circ J. 2014;78(3):619-24.

8. Pérez Matos AJ, Swaans MJ, Rensing BJWM, Heijmen RH, Mast EG, Boersma LVA, et al. Embolization of a left atrial appendage closure device unmasked by intermittent left bundle branch block. JACC Cardiovasc Interv. 2014;7(9): e115-7.

9. Chopra M, Wong $\mathrm{YH}$, Sondergaard L, De Backer O. Percutaneous retrieval of an embolized left atrial appendage closure device from the left atrium in a patient with previous MitraClip. BMC Cardiovasc Disord. 2019;19:196. https:// doi.org/10.1186/s12872-019-1170-8.

10. Reddy W, Gibson DN, Kar S, O'Neill W, Doshi SK, Horton RP, et al. Postapproval U.S. experience with left atrial appendage closure for stroke prevention in atrial fibrillation. J Am Coll Cardiol. 2017 Jan 24;69(3):253-61.

11. Boersma LVA, Schmidt B, Betts TR, Sievert H, Tamburino C, Teiger E, et al. Implant success and safety of left atrial appendage closure with the WATCHMAN device: peri-procedural outcomes from the EWOLUTION registry. Eur Heart J. 2016 Aug;37(31):2465-74.

12. Reddy $W$, Sievert H, Halperin J, Doshi SK, Buchbinder M, Neuzil P, et al. Percutaneous left atrial appendage closure vs warfarin for atrial fibrillation: a randomized clinical trial. JAMA. 2014 Nov 19;312(19):1988-98.

13. Pillarisetti J, Reddy YM, Gunda S, Swarup V, Lee R, Rasekh A, et al. Endocardial (watchman) vs epicardial (lariat) left atrial appendage exclusion devices: understanding the differences in the location and type of leaks and their clinical implications. Heart Rhythm. 2015 Jul;12(7):1501-7.

14. Betts TR, Leo M, Panikker S, Kanagaratnam P, Koa-Wing M, Davies DW, et al. Percutaneous left atrial appendage occlusion using different technologies in the United Kingdom: a multicenter registry. Catheter Cardiovasc Interv Off J Soc Card Angiogr Interv. 2017;89(3):484-92.

15. Saw J, Fahmy P, Azzalini L, Marquis J-F, Hibbert B, Morillo C, et al. Early Canadian multicenter experience with WATCHMAN for percutaneous left atrial appendage closure. J Cardiovasc Electrophysiol. 2017 Apr;28(4):396-401.

16. Fanari Z, Goel S, Goldstein JA. Successful percutaneous retrieval of embolized transcatheter left atrial appendage closure device (watchman) using a modified vascular retrieval forceps. Cardiovasc Revasc Med. 2017; 18(8):616-18.

17. Gabriels J, Beldner S, Khan M, Zeitlin J, Jadonath R, Patel A. Embolization of watchman device following a hybrid radiofrequency ablation of atrial fibrillation and watchman implantation procedure. J Cardiovasc Electrophysiol. 2017 Jul;28(7):835-6.

18. Fastner C, Lehmann R, Behnes M, Sartorius B, Borggrefe M, Akin I. Venovenous double lasso pull-and-push technique for transseptal retrieval of an embolized watchman occluder. Cardiovasc Revascularization Med Mol Interv. 2016;17(3):206-8.

19. Deng H, Liao H, Liu Y, Chen S, Xue Y, Zhan X, et al. Acute heart failure caused by dislocation of a WATCHMAN left atrial appendage Occluder. JACC Cardiovasc Interv. 2016 May 23;9(10):e97-9.

20. Stöllberger C, Schneider B, Finsterer J. Serious complications from dislocation of a watchman left atrial appendage occluder. J Cardiovasc Electrophysiol. 2007 Aug;18(8):880-1.

21. Barth C, Behnes M, Borgrefe M, Akin I. Peri-interventional embolization of left atrial appendage occlusion devices: two manoeuvers of successful retrieval. Eur Heart J Case Rep. 2018;2(1):yty001.

22. Bösche LI, Afshari F, Schöne D, Ewers A, Mügge A, Gotzmann M. Initial experience with novel Oral anticoagulants during the first 45 days after left atrial appendage closure with the watchman device. Clin Cardiol. 2015 Dec; 38(12):720-4.

23. Obeid S, Nietlispach F, Luscher TF, Alibegovic J. Percutaneous retrieval of an endothelialized AMPLATZER cardiac plug from the abdominal aorta 6 months after embolization. Eur Heart J. 2014;35(47):3387.

24. Aminian A, Lalmand J, Tzikas A, Budts W, Benit E, Kefer J. Embolization of left atrial appendage closure devices: a systematic review of cases reported with the watchman device and the amplatzer cardiac plug. Catheter Cardiovasc Interv. 2015:86(1):128-35.

25. Benic C, Noel A, Fofana A, Pouliquen MC, Didier R, Fatemi M, Mansourati J. P474 Late discovery of a left atrial appendage occluder embolization. EP Europace. 2018;20(suppl_1):i97. https://doi.org/10.1093/europace/euy015.283.

\section{Publisher's Note}

Springer Nature remains neutral with regard to jurisdictional claims in published maps and institutional affiliations. 